\title{
Editorial
}

\section{In Memoriam of Iván Lásló Bonta (1922-2007)}

\author{
Freek J. Zijlstra \\ Department of Anesthesiology, Erasmus MC, P.O. Box 2040, 3000 CA, Rotterdam, The Netherlands
}

Received 20 February 2007; Accepted 20 February 2007

Copyright (C) 2007 Freek J. Zijlstra. This is an open access article distributed under the Creative Commons Attribution License, which permits unrestricted use, distribution, and reproduction in any medium, provided the original work is properly cited.

Professor Emeritus Iván Lásló Bonta, an internationally renowned pharmacologist, died in Rome, Italy, on 6 February 2007 , at age 84 , on the verge of boarding an airplane to Israel. His death is mourned by his family, many colleagues, friends, and former students.

Iván was born on 6 October 1922 in Budapest, Hungary. Due to antisemitic laws, after his grammar school, he was not permitted to pursue medical studies. He survived the 2nd World War in a forced labour camp in Poland. Thereafter, he studied medical science in Budapest and graduated in 1950. He became a doctoral student and obtained his Ph.D. degree in experimental pharmacology, at a research institute of the Hungarian Army. In 1947, he married Vera. In the early 1950s, his son Janos and daughter Zsoka were born. In 1956, following the Russian suppression of the Hungarians, the family decided to leave Hungary and moved to the Netherlands, where he became Head of Pharmacology Research at the drug company Organon.

After successful research activities at Organon, in 1969 he was appointed Professor and Chairman at the Department of Pharmacology of the Medical School of the Erasmus University Rotterdam. In 1992, he retired from the chair, quite reluctantly at the age of 70 years. Prior to his retirement, in 1991 he founded the international scientific journal Mediators of Inflammation (Rapid Communications of Oxford Ltd.), of which the first bimonthly issue was published in February 1992. In 1997 he resigned as Editor-inChief.

After the passing away of his wife Vera in 1996, after a restless period, he searched for new challenges and happiness, which he found in 1997 in Israel, where he met Lea Egózi, whom he married and lived with in Nethanya.

His main line of his research was inflammation and immunopharmacology. During his career, he has been (co)author of more than 225 scientific papers.
During his time at Organon, he already investigated the effects of serotonin and anti-inflammatory agents in the rat paw oedema $[1,2]$. In the Erasmus University Rotterdam, he initiated research with isolated tissue preparations $[3,4]$, performed by his first two Ph.D. students, of whom another twelve would follow through the

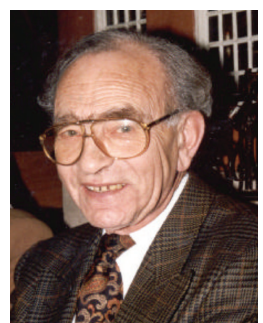

Iván Bonta in 1995. years. At that time, in the early 1970s, prostaglandins were discovered. Their role in platelets and the rat paw model of inflammation were the subject of a number of investigations [5-8]. After the discovery of leukotrienes, their biological activity [9] and role in inflammatory cells were investigated [10-12]. As a next step, the involvement of stimulated macrophages and their substances released were investigated as tools against tumour growth [13-17]. However, not only animal and human cells were subjected to immunopharmacological research activities. In the 1980s, the organ bath technique for isolated human tissue was used to study responses of bioactive substances during inflammation $[18,19]$.

Living in Israel, he initiated research on images of diseases in archaic societies. He was fascinated by pre-Columbian sculpted statuettes which resemble the phenomenology of diseases. Specimens of his impressive private collection have been shown as illustrations in a remarkable book written by him, entitled "Diseased Ancestors: Essays and Stories around Medical Archaeology." In the last years, he was impressed by alternative medicine [20] and associations between schizophrenia, anaesthesia, and near-death experiences [21]. As a result, he wrote a paperback on this subject in Dutch, which has just recently been published.

Iván had a remarkable and also a fruitful life. Through his authorship, research, teaching, and editor's work, he 
contributed substantially to the immunopharmacology. We will all remember him as a person that liked to teach, to be heard, with a vast knowledge and many stories to tell, someone who enjoyed being in the center of life and attention. In general, he was a charismatic, charming, erudite, and enjoyable person, with a lot of very typical humour.

He is survived by his present wife Lea, his son Janos and his wife Gladys, his daughter Zsoka and her husband Edgar, and his three grandchildren, Peter, Ilana, and Anne.

On Sunday 11 February 2007, we buried him in the Jewish cemetery in Rotterdam, next to his first wife Vera as he wished it to be.

\section{Freek J. Zijlstra}

\section{REFERENCES}

[1] I. L. Bonta and C. J. de Vos, "Presence of a slow-contraction inducing material in fluid collected from the rat paw oedema induced by serotonin," Experientia, vol. 21, no. 1, pp. 34-35, 1965.

[2] I. L. Bonta, N. Bhargava, and C. J. de Vos, "Specific oedemainhibiting property of a natural anti-inflammatory factor collected from inflamed tissue," Experientia, vol. 26, no. 7, pp. 759-760, 1970.

[3] D. W. Hall and I. L. Bonta, "The biphasic response of the isolated guinea-pig ileum by bradykinin," European Journal of Pharmacology, vol. 21, no. 2, pp. 147-154, 1973.

[4] A. L. Frankhuijzen and I. L. Bonta, "Role of prostaglandins in tone and effector reactivity of the isolated rat stomach preparation," European Journal of Pharmacology, vol. 31, no. 1, pp. 44-52, 1975.

[5] H. Bult and I. L. Bonta, "Rat platelets aggregate in the absence of endogenous precursors of prostaglandin endoperoxides," Nature, vol. 264, no. 5585, pp. 449-451, 1976.

[6] J. E. Vincent, I. L. Bonta, and F. J. Zijlstra, "Platelets and mediators in the carrageenin rat paw oedema," Agents and Actions. Supplements, vol. 2, pp. 41-46, 1977.

[7] M. J. Parnham, I. L. Bonta, and M. J. P. Adolfs, "Cyclic AMP and prostaglandin $\mathrm{E}$ in perfusates of rat hind paws during the development of adjuvant arthritis," Annals of the Rheumatic Diseases, vol. 37, no. 3, pp. 218-224, 1978.

[8] P. C. Bragt and I. L. Bonta, "In vivo metabolism of [1$\left.{ }^{14} \mathrm{C}\right]$ arachidonic acid during different phases of granuloma development in the rat," Biochemical Pharmacology, vol. 28, no. 10 , pp. 1581-1586, 1979.

[9] F. J. Zijlstra, I. L. Bonta, M. J. P. Adolfs, and J. E. Vincent, "Isoprenaline inhibits the leukotriene $\mathrm{C}_{4}$-induced release of thromboxane $\mathrm{A}_{2}$ from guinea pig lung parenchyma," European Journal of Pharmacology, vol. 76, no. 2-3, pp. 297-298, 1981.

[10] E. J. Schenkelaars and I. L. Bonta, " $\beta_{2}$-adrenoceptor agonists reverse the leukotriene $\mathrm{C}_{4}$-induced release response of macrophages," European Journal of Pharmacology, vol. 107, no. 1, pp. 65-70, 1984.

[11] R. J. Ouwendijk, F. J. Zijlstra, J. H. Wilson, J. E. Vincent, and I. L. Bonta, "Production of leukotrienes and prostaglandins by human ascites cells," European Journal of Clinical Investigation, vol. 15, no. 6, pp. 327-331, 1985.

[12] J. A. Van Hilten, G. R. Elliott, and I. L. Bonta, "Specific lipoxygenase inhibition reverses macrophage cytotasis towards P815 tumor cells in vitro induced by the calcium ionophore A23187," Prostaglandins Leukotrienes and Essential Fatty Acids, vol. 34, no. 3, pp. 187-192, 1988.
[13] G. R. Elliott, C. Tak, C. Pellens, S. Ben-Efraim, and I. L. Bonta, "Indomethacin stimulation of macrophage cytostasis against MOPC-315 tumor cells is inhibited by both prostaglandin $\mathrm{E}_{2}$ and nordihydroguaiaretic acid, a lipoxygenase inhibitor," Cancer Immunology Immunotherapy, vol. 27, no. 2, pp. 133-136, 1988.

[14] M. W. J. A. Fieren, G. J. C. M. Van den Bemd, and I. L. Bonta, "Endotoxin-stimulated peritoneal macrophages obtained from continuous ambulatory peritoneal dialysis patients show an increased capacity to release interleukin- $1 \beta$ in vitro during infectious peritonitis," European Journal of Clinical Investigation, vol. 20, no. 4, pp. 453-457, 1990.

[15] F. D. Beusenberg, A. van Schaik, J. G. C. van Amsterdam, and I. L. Bonta, "Involvement of eicosanoids in platelet-activating factor-induced modulation of adenylyl cyclase activity in alveolar macrophages," Journal of Lipid Mediators, vol. 3, no. 3, pp. 301-309, 1991.

[16] I. M. Garrelds, F. J. Zijlstra, C. J. A. M. Tak, I. L. Bonta, I. Beckmann, and S. Ben-Efraim, "A comparison between two methods for measuring tumor necrosis factor in biological fluids," Agents and Actions, vol. 38, pp. C89-C91, 1993.

[17] W. M. Pruimboom, A. P. M. van Dijk, C. J. A. M. Tak, I. L. Bonta, J. H. P. Wilson, and F. J. Zijlstra, "Production of inflammatory mediators by human macrophages obtained from ascites," Prostaglandins Leukotrienes and Essential Fatty Acids, vol. 50, no. 4, pp. 183-192, 1994.

[18] J. C. de Jongste, H. Mons, R. Van Strik, I. L. Bonta, and K. F. Kerrebijn, "Comparison of human bronchiolar smooth muscle responsiveness in vitro with histological signs of inflammation," Thorax, vol. 42, no. 11, pp. 870-876, 1987.

[19] R. C. Jongejan, J. C. de Jongste, R. C. Raatgeep, T. Stijnen, I. L. Bonta, and K. F. Kerrebijn, "Effects of inflammatory mediators on the responsiveness of isolated human airways to methacholine," American Review of Respiratory Disease, vol. 142, no. 5, pp. 1129-1132, 1990.

[20] I. L. Bonta, "Acupuncture beyond the endorphin concept?" Medical Hypotheses, vol. 58, no. 3, pp. 221-224, 2002.

[21] I. L. Bonta, "Schizophrenia, dissociative anaesthesia and neardeath experience; three events meeting at the NMDA receptor," Medical Hypotheses, vol. 62, no. 1, pp. 23-28, 2004. 


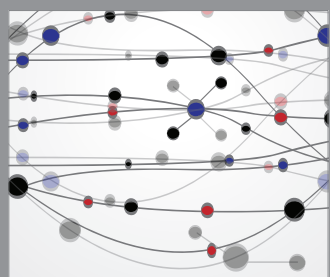

The Scientific World Journal
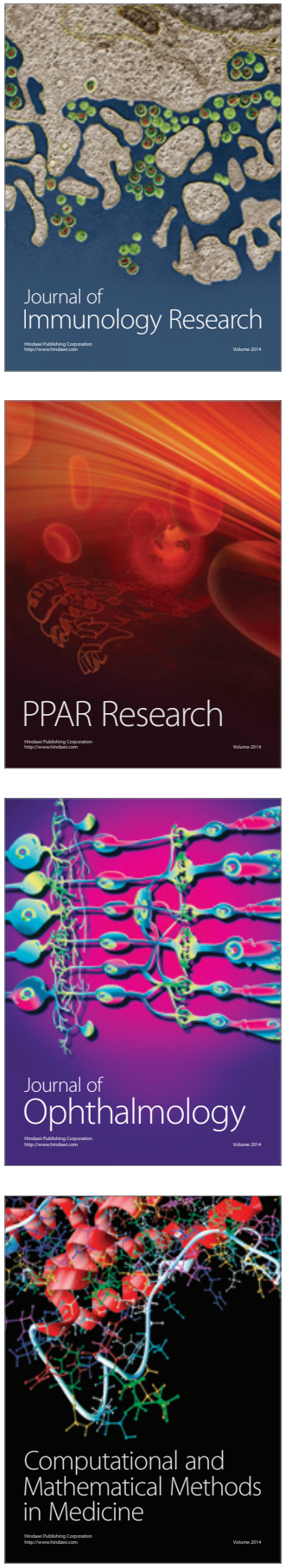

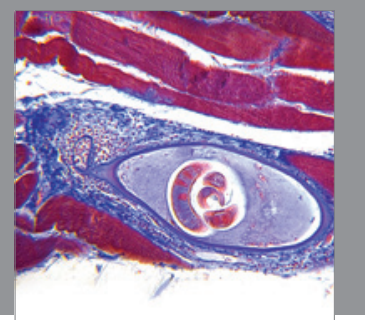

Gastroenterology

Research and Practice
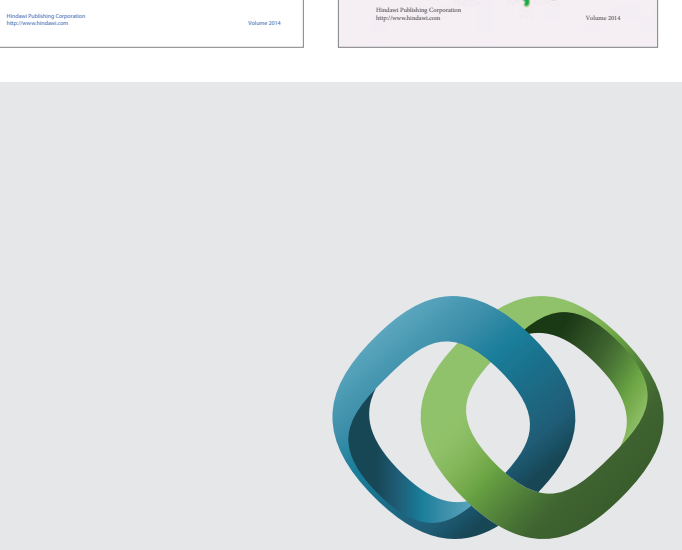

\section{Hindawi}

Submit your manuscripts at

http://www.hindawi.com
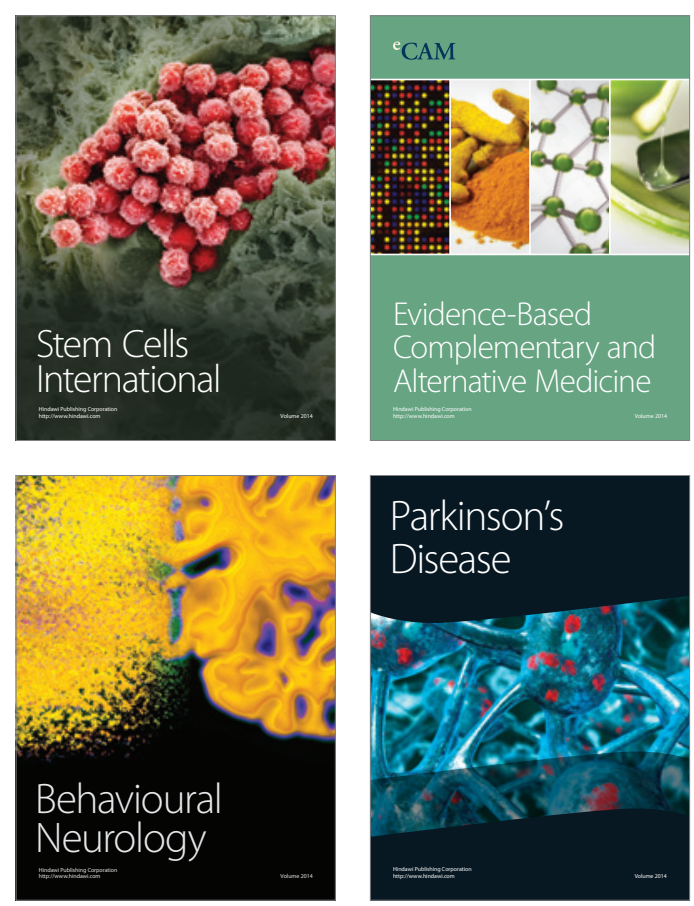

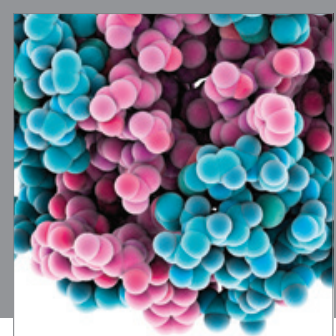

Journal of
Diabetes Research

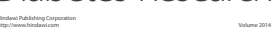

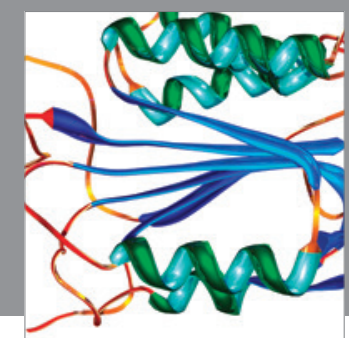

Disease Markers
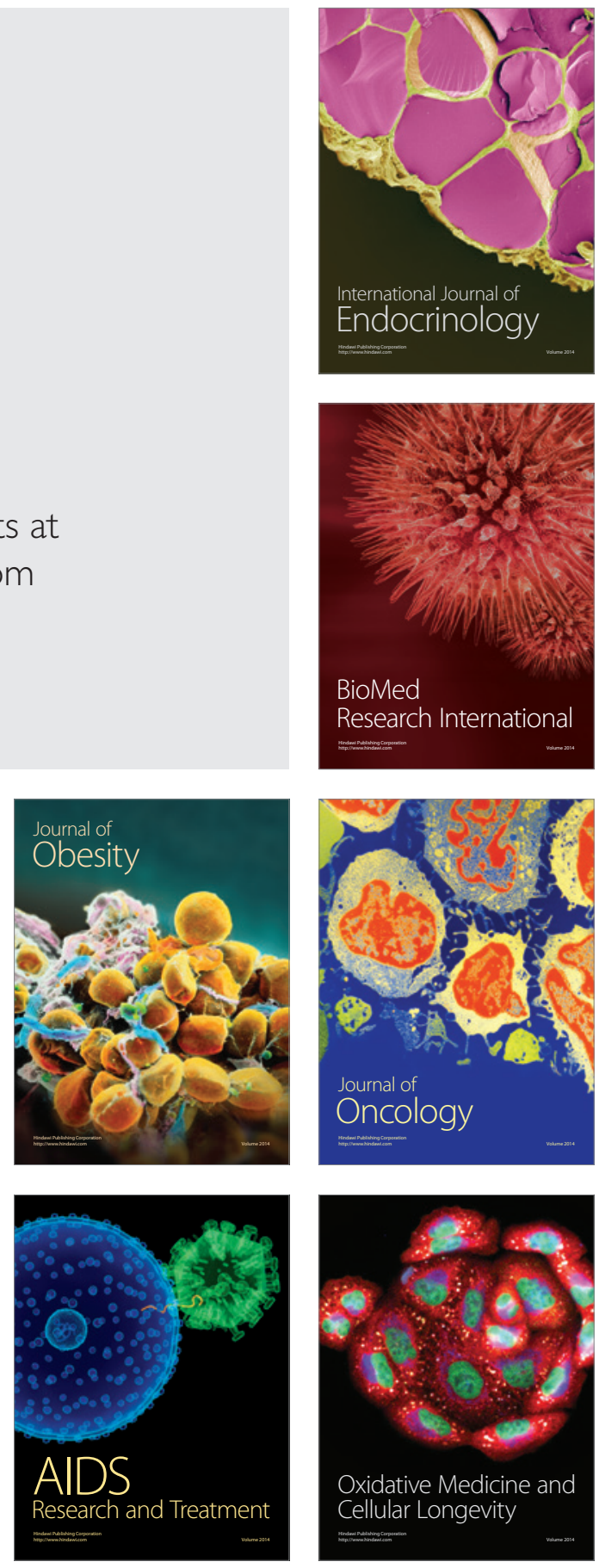